\title{
BEYOND DANGDUT: NURTURING LOCAL LANGUAGE USING LYRICS
}

\author{
Ferdi Arifin \\ Tadris Bahasa Indonesia - Fakultas Adab dan Bahasa \\ Institut Agama Islam Negeri Surakarta \\ ferdiarf@gmail.com
}

\begin{abstract}
Abstrak
Isu kepunahan bahasa akbir-akhir ini menjadi sangat serius ketika pemerintah menginformasikan bahwa ada 11 bahasa daerah punah dalam 15 hari. Di sisi lain, Badan Pengembangan dan Pelestarian Bahasa sudah secara optimal menjalankan upaya revitalisasi bahasa-bahasa di daerah tetapi kepunahan bahasa tetap saja terjadi. Penelitian ini akan melakukan kritik terbadap upay a pelestarian bahasa yang dilakukan oleh pemerintah dan memberikan saran kepada pemerintah untuk mengimplementasikan cara baru dalam pelestarian bahasa melalui kepopuleran lagu dangdut berbahasa daerah. Metode yang digunakan dalam penelitian ini menggunakan kualitatif dengan pendekatan linguistik perencanaan untuk melihat sejaub mana efektifitas dangdut dalam upaya pelestarian bahasa di era revolusi industri. Hasil penelitian ini menunjukkan rekomendasi kepada pemerintah untuk mengimplementasikan cara populer dalam pelestarian bahasa daerah melalui penggunaan lagu-lagu dangdut berbahasa daerah untuk meningkatkan kesadaran berbahasa daerah bagi masyarakat Indonesia.
\end{abstract}

Kata Kunci: Musik Dangdut; Pelestarian Bahasa Daerab; Dangdut Sebagai Cara Melestarikan Bahasa Daerah

\begin{abstract}
Endangered language issue recently becomes serious problem when government reports that there are 11 extinct local language in 15 days. Beside, The Language Development and Cultivation Agency has tried optimally to conserve local languages but it is not totally success. This study would take a critic againts goverment for language preservation and recommend to government for implementing new method for language preservation by using dangdut with local language usage in the lyrics. The method used in this study employs qualitatif and it thus applies language planning approach to find out the effectiveness of dangdut as for language preservation in industrial revolustion. The result shows recommendation to government to implies popular way for local language preservation through using dangdut songs with local language usage for the lyrics in order to enhance local language usage awarness among Indonesian.
\end{abstract}

Keywords: Dangdut Music; Local Language Preservation; Dangdut As $A$ Way to

Preserve Local Language

\section{PENDAHULUAN}

Endangered language is being main concern of linguists recently because many languages across the world are losing speakers. UNESCO ${ }^{(2003)}$ notes that $50 \%$ of all languages are fragile, it means that a half of speakers has decresed recently. Campbell et all. ${ }^{(2013)}$ report that $24 \%$ linguistic diversity has already been lost from 420 language families. He also notes that ELCat (Catalogue of Endangered Languages) finds that a language becomes extint per month. In other word, endangered language is linguistic problem seriously in modern world.

Case in Indonesia, there are 11 local language have already lost and 6 local language are threatened with extinction. The languages that already lost derive from Moluccas and Papua (Rachmawati 2018). Meanwhile, UNESCO annouces to mass media that one of local language of Indonesia has been extinc for 15 days (Nurdiarsih 2018). Language extinction or endangered language must be paid attention by 
government to take revitalization ways of local languages in Indonesia.

To understand kinds of endangered language some linguists suggest framework or schema for classifying language according to degree of viability with terminology and designators (Krauss 2007).

Tabel 1. Schema for Classifying Language

\begin{tabular}{|c|c|}
\hline Safe & \\
\hline Stable & all speak, children \& up \\
\hline $\begin{array}{l}\text { instable } \\
\text { erode }\end{array}$ & $\begin{array}{l}\text { some children spea; all } \\
\text { children speak in some places }\end{array}$ \\
\hline $\begin{array}{l}\text { definetively } \\
\text { endangered }\end{array}$ & $\begin{array}{l}\text { spoken only by parental } \\
\text { generation and up }\end{array}$ \\
\hline $\begin{array}{l}\text { severely } \\
\text { endangered }\end{array}$ & $\begin{array}{l}\text { spoken only by grandparental } \\
\text { generation and up }\end{array}$ \\
\hline $\begin{array}{l}\text { critically } \\
\text { endangered }\end{array}$ & $\begin{array}{l}\text { spoken only by very few, of } \\
\text { great-grandparental } \\
\text { generation }\end{array}$ \\
\hline extinct & no speakers \\
\hline
\end{tabular}

By the schema for classifying language, I assume that many local languages of Indonesia have been paid attention to the fragility. Industrial era emerges with many challanges for people nurturing either language, culture, or psychological behavior. Therefore, nurturing local language in industrial era is not easy for speakers.

As we know that most parents speak national language, which is bahasa Indonesia, rather than local language. Instead of adjusting to environtment, it actually degerates local language. For instance in Javanese, word jambon 'pink' does not exist among children because they only know pink or merah muda. Another, word jangan refers to kind of soup in English cannot be understood by children. They tend to say sayur 'vegetable' in bahasa Indonesia.

Javanese is the language with the most speakers in Indonesia (Koran Sindo 2017) even Javanese is also in 20 most spoken languages around the world. Even though Javanese is considered as most popular language in Indonesia and as 20 most spoken language of the world but industrial revolution is able to influence as well as other languages. I assume that Javanese language is able to be influenced by industrial revolution, it means that other languages, which have less speakers, are easily endangered.

The Language Development and Cultivation Agency as representative of Ministry of Education has programs to maintain local culture either language or literature. Most programs determine to conservating and revitalizing local languages (Kompas.com 2017). By design, the programs of conservating can be elaborated as system compilation of phonology, syntax, morphology, and orthography; and of revitalizing can be understood as local language learning, preparation of learning materials, and local language festival (Harimansyah 2017).

However, The Language Development and Cultivation Agency program tends to less implementative because process of implemented program cannot reach the roots. As language itself is device for people communicate to each others. So, fostering language should be in touch to root of problems.

I observe Javanese language is hardly be maintained by government programs. As millennials, They got javanese lecturer when they were in school but they are now prefer using bahasa Indonesia to speak with children or older rather than Javanese. I assume that revitalizing language designed by government is not quite effective for nurturing the language.

Meanwhile, I examine dangdut, as music genre, is more effective to people notice about local language. For instance, Via Vallen's song Sayang is effective to spread people's pride of local language, which is Javanese. Most Indonesian know how to sing Sayang although they are not Javanese society. In other word, Dangdut is more effective to invite people aware of local language pride rather than to learn the language in school.

As reasons above, language development and cultivation can be related to dangdut performance by local lyrics. According to Wierzbicka (1992) language represents speaker itself, so nurturing language means that preserving local identity. Crystal (2000) also points out that a language can be deprived fi the speakers are less used in educational, political and other public situation. Therefore, I conduct this research to examine dangdut as a way to develop and cultivate local language effectively.

The implication of industrial revolution as a reason of waekening of local language as ethnic identity warrant further research through two questions. Firts, we will find out how dangdut encourages individuals to notice the lyrics. Second, this article discusses how effective dangdut 
influences society to cultivate local language as ethnic identities.

So far, research for dangdut tends to find out the local culture (Daniels 2013; Bader 2011; Pioquinto 1995); the gender and identity (David 2014; Browne 2000); music, lyric, and (Rahayu 2018; Arifin 2017; Permana 2019; Fahrudin and Barakbah 2018). As research for dangdut focuses on certain topic that refers to culture, gender, identity, music, and performance. Even, some researches conducted are focusing on lyrics tend to find out the meaning only. In other hand, dangdut lyrics does not specifically be studied for language preservation it means that novelty of this article is renewable.

\section{METODE}

As we know method is a main research aspect to gain data collection, to analyze classifying data, and to provide audience for research report. In particular, method is very important for making reasonable research and delivering research result. This article employs qualitative approach because it uses a wide variety of data collections, which are observation, interviews, open-response questionnaire items, verbal reports, diaries, and discourse analysis (Croker 2009). However, I would like to propose to take of two aspects which are observation and discourse analysis to obtain data. I observe dangdut lyrics as particular language supported in public mind. Christ 1995 views particular language as public validity. According to Wodak (2006) aspects of language usage allow systematical empiric research for language policy. Therefore, language usage on dangdut lyrics has potential aspect to be raised as policy in particular way.

Meanwhile, a wide variety of data would be complex so there needs to be limitations. I assure that Javanese dangdut lyrics would be representative as we know that Javanese speakers are the most numerous in Indonesia. Yet, youth Javanese generation do not pay attention to preserve the language rather they prefer speaking bahasa Indonesia to Javanese language in daily life.

In addition, there are Javanese dangdut songs being popular among Indonesian. Even Javanese dangdut song can be sung by Indonesian who is not Javanese. I assure that Javanese dangdut song is able to be a way to organize local language policy.
In other words, this article examines Javanese dangdut song as a solution for nurturing local language in industrial revolution by observing dangdut phenomena among Indonesian and analyzing dangdut lyrics as a way to preserve local language among youth generation.

\section{HASIL DAN PEMBAHASAN}

\section{DANGDUT PHENOMENA AMONG}

\section{INDONESIAN}

"Dangdut is the music of my country" Project Pop band

Quotation above is popular among 90th generation because it is a music tittle of Project Pop band. Dangdut has bee existed since 1970s. Dangdut itself is arguably its most hybrid, blending Melayu, Arabic, and Indian music elements it is also being considered as proletarian character and association with sinful likely Algerian rai and Turkish Arabesque (Wallach 2002). Afterward dangdut rebrands the image as conveying Islamic message in Rhoma Irama era (Frederick 1982).

Dangdut itself derived from a sound dang and dut. The naming dangdut comes from the basic instruments which consist of guitar, bass, drums, electronic keyboard, mandolin, tambourine, gendang and suling (Weintraub 2006). Because of the instruments, dangdut is being popular music for easy listening to society.

Dangdut's popularity is based on its ability to adapt to any conditions it proves that dangdut still exists nowadays. New Magazine Tempo labeled 1979 'the year of dangdut' and published the first historical account of the genre in a cover story entittle 'The day of dang duts' (Weintraub 2006).

In Soeharto regime, dangdut had obstacles like not be promoted in television or other shows by government. Even Rhoma Irama was banned from performing on TVRI because of his music was being a symbol of resistance againts the New Order military regime especially toward Golkar (Sen and Hill 2000).

Dangdut problematic was not only coming from banning but also visualizing as low-class people. Its music was placed in relation to other competing genres of popular music in order to make distinctions among different class of people (Weintraub 2006). According to Yampolsky (1995) and Williams (1990) have researched for popular music of Indonesia rather dangdut dangdut was 
associated to low-class people for reflecting on poverty, unemployment, loss, and despair.

In 1991, dangdut raised popularity across the world. One of dangdut song Kopi Dangdut was celebrated as the fourth most popular album in Japan, demonstating dangdut's global market strength, and promoting national pride. Global market made dangdut well-known as Indonesian identity, so MTV Asia firstly aired dangdut music in 1999 (Weintraub 2006).

Popularity of dangdut led society interest of Indonesia that brought the genre developed to another form well-known as dangdut koplo. The term of Koplo derives from East Java and refers to music beat, performance, and tones. Lexically, koplo itself comes from a kind of medicine that is popular among Indonesian. It became rapidly famous early 1990 to 2000s after former president Soeharto regime (Weintraub 2010).

As opposed to popularity dangdut around the world, 2006s came up morality issue on dangdut performing arts. Inul Daratista deliberately sang dangdut with erotic dance in her performance. Rhoma Irama, together with others, attacked Inul Daratista degenerated the status of dangdut by exposing her erotic movements.

Inul's discourse involved Abdurahman Wahid as former president spoke to Rhoma and Inul to find out the main issue of degenerating dangdut and woman dignity. Cultural critic Emha Ainun Nadjib also stated than Inul's discourse was representing the people in his writing opinion. Nevertheles, another opinion about its discourse claimed that the issue related to Indonesian woman's role (van Wichelen 2005).

Historically dangdut has faced many trials in the journey. However, dangdut have successed gaining popularity from Indonesian lately. It refers to many dangdut singers airs on national television either state or privat channel. One of popular dangdut singer who has many followers is Via Vallen. Her successful led her to become most talanted dangdut singer for being main singer at ASEAN Games.

Popularity dangdut singer cannot be seperated by Youtube channel. For instance, Via Vallen itself becomes popular among Indonesian because of her uploaded cover song activelly in her Youtube channel. Instead, her Youtube channel have reached around 106 million viewers per day with estimated earning from Youtube around US\$
1.500 a day (Socialblade.com 2019b). Even her popularity as dangdut singer leads her new single song heading to get million viewers a day (Idntimes.com 2019).

In addition, dangdut popularity also raises TV show D'Academy Indosiar that has been popular since 2014. Even it became most popular and rating TV Show summit in the same year (Rayendra 2014).

Therefore, dangdut popularity can be seen as a new influence for society. I thus propose to optimize the dangdut popularity as a media to influence people having awarness for cultivating local language. I assure that it would be more effective for cultivating local language rather than fostering language in lecturing. For instance, Bojo Galak (fierce wife/husband) song of Pendhoza sang by Via Vallen has been massive influence for Indonesian aware of Javanese language. Via Vallen's popularity lifted up the song to be cover and cover again by others, such as Ria Ricis who is influenncer and has the most numerous subscribers in Asean (Socialblade.com 2019a). In fact, Ria Ricis is not Javanese but she sings Javanese dangdut song for the popularity. In other words, popularity of dangdut can be employed to be a solution of cultivating local language in order to Indonesian has awarness for nurturing local language especially Javanese language.

\section{DANGDUT LYRICS FOR NURTURING LOCAL LANGUAGE: CRITICS AGAINST THE LANGUAGE DEVELOPMENT AND CULTIVATION AGENCY}

Nurturing language is not easy to be done by any linguist. In Indonesia, nurturing language always relates to government institution wellknown as The Language Development and Cultivation Agency as representing of Ministry of Education. There are two aspects for nurturing the language held by the government institution which are conservation and revitalization.

Conservation itself is considered as a way to foster and protect the language from endangered language. Sometimes, it is always well-knows as language preservation that it means protecting and maintaining the language to make its language stay away from insecurity. It has procedure of conservation itself, which are developing of system phonology, morphology, syntax, and ortography (Harimansyah 2017). 
In other hand, revitalization is defined as an effort to enhance forms and functions of language usage from either endangered language or language loss (King 2001). The Language Development and Cultivation Agency of Indonesia begins revitalization as a procedure for local language learning either classical way likely learning in class or community way such a language peer group continuously (Harimansyah 2017).

As simply, conservation and revitalization held by the government program is systematically research proper. It is cause the program held is based on the input of language mapping comprehensively then it takes language conservation by design syatematical compilation of phonology, morphology, syntax, and ortography. Thus, the result of systematical compilation is going to be formulated into learning material, provision of learning system, and language festival.

Based on the research line, the program is not having mistake to take conservation and revitalization local language of Indonesia. Yet, endangered local language in Indonesia remains exist. In fact, there are 11 local language have been lost in Indonesia for 15 (Nurdiarsih 2018; Rachmawati 2018). It means that deficiency of the agency's program is really happening.

I would not blame for the program instead of proposing new concept of nurturing local language corresponding to the occasions recently. I assure that maintaining language is about neither teach it nor learn it. However, nurturing language cannot be separated with practical things.

Language planning is important to maintaining local language. It refers to deliberate efforts to influence the behavior of others with respect to the acquisition, structure, or functional of language (Bianco 2004). It means that language policy can be defined as the combination of official decision and prevailing public practices related to language education and use (McGroarty 1997).

Based on the explanation above we can assume that program of The Language Development and Cultivation Agency has already been on the track as language planning for official decision to language education and use. Yet, there is deficiency procedure for deliberating efforts to influence behavior of others with respect to the local language.

Here, I would propose to utilize one of popular dangdut lyrics as a way to admonish that local language is exist and used in the lyrics. Firstly, I would provide that dangdut lyrics represent to deliberate efforts to influence people behavior.

\section{Kuat dilakoni, lek ra kuat ditinggal ngopi}

Tetep cinta senajan bojoku galake

These lyrics are meaningful among Indonesia who has local culture for spending leisure time with a cup of coffee. Coffee is the best partner for taking a rest lonely or communally that means the lyrics internalize Indonesian mind. Therefore, dangdut popularity comprehends to society that makes it touches their behavior.

Secondly, dangdut lyrics lead audiences to aware of the language usage that are rarely used in daily conversation.

Tak tompo nganggo tulus ing ati

Tak trimo sliramu tekan saiki

Mungkin wes dadi jodone

Senajan kahanane koyo ngene

Ibarate dele sing unis dadi tempe

Kudu tak lakoni yen pancen ngene dalane

Abote nduwe bojo sing galak

Lek ra keturutan senengane mencak-mencak.

Some of dangdut lyrics are seldom utteranced in daily life. For instance, words sliramu 'you' and mencak-mencak 'be angry' are not really understood by children nowadays. Perhaps, children can sing the song but they do not really understand the meaning of two words. It is able to be proved in social media facts. Language usage of sliramu and mencak-mencak, would not be used by children nowadays.

Dangdut lyrics are popular among Indonesian but some of them who are really understood the meaning of words semantically. In other words, people enjoy the lyrics but they tend to not understand about the meaning clearly. As if we borrow Weintraub (2006) definition it is called as dangdut soul.

The reason why do this study propose dangdut lyrics as other method to maintain local language. It is based on the fact that language a tool for communication among people and language itself can be obtained by practice. I assure that practice makes better for nurturing the language. 
According to Lynch and Mendelsohn (2010) explored that listening skill drawn some concept into the mind. There are two important aspects of listering for nurturing the local language, which are enabling skill and enacting skill. I would elaborate those concepts in tabel.2.

Tabel 2. Listening Comprehension

\begin{tabular}{|c|c|}
\hline Enabling Skill & Enacting Skill \\
\hline $\begin{array}{l}\text { Perception } \\
\text { Recognizing } \\
\text { prominence within } \\
\text { utterances } \\
\text { Interpretation } \\
\text { Formulating content } \\
\text { sense of an utterance, } \\
\text { Formulating } \\
\text { conceptual } \\
\text { framework linking } \\
\text { utterances, } \\
\text { Interpreting } \\
\text { (possible) speaker } \\
\text { intentions }\end{array}$ & $\begin{array}{l}\text { - Selecting key } \\
\text { points for the } \\
\text { current task } \\
\text { Transcoding } \\
\text { information into } \\
\text { written form } \\
\text { (for example, } \\
\text { notes) } \\
\text { - Identifying } \\
\text { which points } \\
\text { need } \\
\text { clarification } \\
\text { - Integrating } \\
\text { information } \\
\text { with that from } \\
\text { other sources } \\
\text { Providing } \\
\text { appropriate } \\
\text { feedback to the } \\
\text { speaker }\end{array}$ \\
\hline
\end{tabular}

Listening to dangdut is a way to enactive listening comprehensive skills to understand the language usage in the lyrics. Dangdut popularity is enable to build perception and interpretion from the audiences which means they would unconsciously transcoding information, identifying the lyrics, integrating information with that from other sources, and providing appropriate feedback as revitalization the language.

It can be provided in Ria Ricis Official Youtube channel when she covered Bojo Galak song on her channel reaching 3.2 million viewers (Socialblade.com 2018a) and Kanca Mesra song around 3.8 million viewers (Socialblade.com 2018b). The main thing is the subscribers of Ricis Offical has been dominated by Indonesian children (Kontan.co.id 2019).

Via Vallen performance on NET TV birthday celebration amazed audiences when she sang Sayang song. Even the uploaded video of Via
Vallen performance on Youtube reached 26 million viewers (Socialblade.com 2018c). It refers to Via Vallen's popularity as dangdut singer touches the audiences' behavior.

By the fact, I criticize The Language Development and Cultivation Agency programs on conservation and cultivation the local language is not enough for recent phenomena. In particular, the agency programs held tend to be formal and it is considered as boring event for generation nowadays.

The implication of understanding dangdut lyrics leads the audiences to admonish society to be unconcsciously aware for nurturing local language based on the dangdut lyrics, such as Via Vallen songs. However, language preservation is able to spread widely through the social media of Youtube because social media has glued with children nowadays.

\section{PENUTUP}

Industrial revolution lifts up society to face advanced technology and information. It means that recent generation cannot be separated with social media. In other words, effectiveness of language preservation should be related to the new trend among now generation.

Nurturing local language from dangdut lyrics has been promoted on social media because the media itself is popular among recent generation. The components of dangdut itself become effective to deliver the message for language preservation because of singer popularity and language touched of lyrics.

By those components, delivering language preservation towards recent generation becomes unconsciously acquired by society through their enacting reproduction of language usage on dangdut lyrics.

Finally, I recommend to government especially for The Language Development and Cultivation Agency to imply language preservation modernly by using dangdut lyrics. It becomes effective to preserve local languageas as if the lyric is touching, the singer is popular, and the media is precise. In other words, language preservation would become fun and acquirable when the method used is suitable with recent generation. 


\section{DAFTAR PUSTAKA}

Arifin, Ferdi. 2017. "Citra Perempuan Dalam Lirik Lagu Kimcil Kepolen Karya Ndx Aka Familia Dalam Perspektif Linguistik Kognitif." Jurnal Babasa Lingua Scientia 9 (2): 161-76. https://doi.org/10.21274/1s.2017.9.2.161176.

Bader, Sandra. 2011. "Dancing Bodies on Stage." Indonesia and the Malay World 39 (115): 33355.

https://doi.org/10.1080/13639811.2011.61 4085 .

Bianco, Joseph Lo. 2004. "Language Planning as Applied Linguistics." In The Handbook of Applied Linguistics, edited by Alan Davies and Catherine Elder, 738-62. Oxford: Blackwell Publishing.

Browne, Susan. 2000. "The Gender Implications of Dangdut Kampungan: Indonesian LowClass Popular Music." 109. 0314-6804. Melbourne.

Campbell, Lyle, Raina Heaton, Nala Lee, Eve Okura, Sean Simpson, Kaori Ueki, and John Van Way. 2013. “New Knowledge: Findings from the Catalogue of Endangered Languages ('ELCat ')." In International Conference on Language Documentation and Conservation. Honohulu: University of Hawaici.

Croker, Robert A. 2009. "An Introduction to Qualitative Research.” In Qualitative Research in Applied Linguistics: A Practical Introduction, edited by Juanita Heigham and Robert A. Croker, 3-41. New York: Palgrave Macmillan.

Crystal, David. 2000. Language Death. Cambridge: Cambridge University Press.

Daniels, Timothy P. 2013. "Social Drama, Dangdut, and Popular Culture." In Performance, Popular Culture, and Piety in Muslim Southeast Asia, edited by Timothy P. Daniels, 161. New York: Palgrave Macmillan.

David, Bettina. 2014. "Seductive Pleasures, Eluding Subjectivities: Some Thoughts on Dangdut's Ambiguous Identity." In Sonic Modernities in the Malay World: A History of
Popular Music, Social Distinction and Novel Lifestyles (1930s-2000s), edited by Bart Barendregt, 249-70. Leiden: BRILL.

Fahrudin, Tresna Maulana, and Ali Ridho Barakbah. 2018. "Lyric Text Mining Of Dangdut: Visualizing The Selected Words And Word Pairs Of The Legendary Rhoma Irama's Dangdut Song In The 1970s Era." SYSTEMIC: Information System and Informatics Journal 4 (2): 9-17. https://doi.org/https://doi.org/10.29080/ systemic.v4i2.432.

Frederick, William H. 1982. "Rhoma Irama and the Dangdut Style: Aspects of Contemporary Indonesian Popular Culture." Indonesia 34: 102-30. https://doi.org/10.2307/3350952.

Harimansyah, Ganjar. 2017. Pedoman Konservasi Dan Revitalisasi Bahasa. Edited by Mustakim and Wawan Prihantoro. Jakarta: Badan Pengembangan dan Pembinaan Bahasa.

Idntimes.com. 2019. "Ditonton Jutaan Orang Dalam Sehari, 5 Fakta Single Terbaru Via Vallen.” Www.Idntimes.Com. 2019. https://www.idntimes.com/hype/entertain ment/andi-aris/ditonton-jutaan-orangdalam-sehari-5-fakta-single-terbaru-viavallen/full.

King, Kendall A. 2001. Language Revitalization Processes and Prospects: Quichua in the Ecuadorian Andes. Paris: Multilingual Matters LTD.

Kompas.com. 2017. "Perlu Sinergi Pelestarian Bahasa Daerah Artikel Ini Telah Tayang Di Kompas.Com Dengan Judul 'Perlu Sinergi Pelestarian Bahasa Daerah',." Www.National.Kompas.Com. 2017. https://nasional.kompas.com/read/2017/0 2/23/20473671/perlu.sinergi.pelestarian.ba hasa.daerah.

Kontan.co.id. 2019. "Atta, Ricis, Bapau,Dan Raffi.” Www.Analis.Kontan.Co.Id. 2019. https://analisis.kontan.co.id/news/attaricis-bapaudan-raffi.

Koran Sindo. 2017. "Ini Dia, 10 Bahasa Daerah Dengan Penutur Terbanyak Di Indonesia." Www.National.Sindonews.Com. 2017. https:// nasional.sindonews.com/read/1252 853/15/ini-dia-10-bahasa-daerah-dengan- 
Ferdi Arifin: Beyond Dangdut...

penutur-terbanyak-di-indonesia1509344321.

Krauss, Michael. 2007. "Classification and Terminology for Degrees of Language." In Trends in Linguistics Studies and Monographs, edited by Walter Bisang, Hans Henrich Hock, and Werner Winter, 1-8. Berlin . New York: Mouton de Gruyter.

Lynch, Tony, and David Mendelsohn. 2010. "Listening." In An Introduction to Applied Linguistics, edited by Norbert Schmitt, 18096. London: Hodder \& Stoughton Ltd.

McGroarty, Mary. 1997. "Language Policy in the USA: National Values, Local Loyalties, Pragmatic Pressures." In Language Policy: Dominant English, Pluralist Challenges, edited by W. Eggington and H. Wren. Amsterdam: John Benjamins.

Nurdiarsih, Fadjriah. 2018. "UNESCO Ungkap Bahasa Daerah Di Indonesia Punah Setiap 15 Hari Sekali." Www.Liputan6.Com. 2018. https://www.liputan6.com/news/read/346 9714/unesco-ungkap-bahasa-daerah-diindonesia-punah-setiap-15-hari-sekali.

Permana, Catur Surya. 2019. "Dangdut: Java, Reggae and Rap A Collaborative Concept of Via Vallen." In Proceedings of the International Conference on Arts and Design Education (ICADE 2018). Paris, Amsterdam, Hongkong, Beijing: Atalntis Press. https://doi.org/https://doi.org/10.2991/ic ade-18.2019.46.

Pioquinto, Ceres E. 1995. "Dangdut at Sekaten: Female Representations in Live Performance." RIMA: Review of Indonesian and Malaysian Affairs 29 (1): 59-89.

Rachmawati, Ira. 2018. "11 Bahasa Daerah Di Indonesia Dinyatakan Punah, Apa Saja?" Www.Kompas.Com.

2018. https://regional.kompas.com/read/2018/0 2/10/18293411/11-bahasa-daerah-diindonesia-d.

Rahayu, Bety Agustina. 2018. "Dangdut Music Affects Behavior Change at School and Adolescent Youth in Indonesia: A Literature Review." Health Science Journal 12 (1): 1-4. https://doi.org/10.21767/1791809X.1000552.
Rayendra, Panditio. 2014. "Wow! 'Dangdut Academy' Indosiar Puncaki Rating." Www.Tabloidbintang.Com. 2014. https://www.tabloidbintang.com/ film-tvmusik/kabar/read/3641/Wow-DangdutAcademy-Indosiar-Puncaki-Rating.

Sen, Krishna, and David T Hill. 2000. Media, Culture and Politics in Indonesia. Melbourne: Oxford University Press.

Socialblade.com. 2018a. "Ricis Official." Www.Socialblade.Com. 2018. https://www.youtube.com/channel/UC4tS 4Q_Cno5JVcIUXxQOOpA/search?query =bojo+galak.

- 2018b. "Ricis Official." Www.Socialblade.Com. 2018. https://www.youtube.com/channel/UC4tS 4Q_Cno5JVcIUXxQOOpA/search?query $=\mathrm{konco}+$ mesra.

. 2018c. "Via Vallen - Sayang - Indonesian Choice Awards 5.0 NET." Www.Socialblade.Com. 2018. https://socialblade.com/youtube/user/net mediatama/videos/mostviewed.

- 2019a. "Ria Ricis Official." Www.Socialblade.Com. 2019. https://socialblade.com/youtube/channel/ UC4tS4Q_Cno5JVcIUXxQOOpA. 2019b. "Via Vallen Official." Www.Socialblade.Com. 2019. https://socialblade.com/youtube/channel/ UCaHVygCd_tAPmvxVZ85DbDw/month ly.

UNESCO. 2003. "Language Vitality and Endangerment." Paris. http://www.unesco.org/new/fileadmin/M ULTIMEDIA/HQ/CLT/pdf/Language_v itality_and_endangerment_EN.pdf.

Wallach, Jeremy Wayne. 2002. "Modern Noise and Ethnic Accents: Indonesian Popular Music in the Era of Reformasi." University of Pennsylvania.

Weintraub, Andrew N. 2006. "Dangdut Soul: Who Are 'the People' in Indonesian Popular Music?" Asian Journal of Communication 16 (4): 411-31. 
https://doi.org/10.1080/012929806010124

44.

Weintraub, Andrew N. 2010. Dangdut Stories: A Social and Musical History of Indonesia's Most Popular Music. Oxford: Oxford University Press.

Wichelen, Sonja van. 2005. “"My Dance Immoral? Alhamdulillah No!' Dangdut Music and Gender Politics in Contemporary Indonesia." In Resounding International Relations on Music, Culture, and Politics, edited by M.I. Franklin, 161-77. New York: Palgrave Macmillan US.

Wierzbicka, Anna. 1992. Semantics, Cognition, and Culture. London: Oxford University Press.

Williams, Sean. 1990. "Current Developments in Sundanese Popular Music." Asian Music 21 (1): 105-36. https://doi.org/10.2307/834075.

Wodak, Ruth. 2006. "Linguistic Analyses in Language Policies." In An Introduction to Language and Policy: Theory and Method, edited by Thomas Ricento, 170-93. Oxford: Blackwell.

Yampolsky, Philip. 1995. "Indonesian Popular Music: Kroncong, Dangdut, and Langgam Jawa." Performing Arts in Southeast Asia, 700 725.

http://www.jstor.org/stable/27864710. 